\title{
Listening Skills Development in Teaching Turkish as a Foreign Language and The Usage of Metacognitive Strategies
}

\author{
Başak Karakoç Öztürk \\ Correspondence: Başak Karakoç Öztürk, Cukurova University, Turkey. \\ Received: March 25, 2018 \\ doi:10.11114/jets.v6i6.3108 \\ Accepted: April 16, $2018 \quad$ Online Published: April 18, 2018 \\ URL: https://doi.org/10.11114/jets.v6i6.3108
}

\begin{abstract}
The aim of this study is to determine the state of using metacognitive strategies to develop listening skills in teaching Turkish as a foreign language to Syrian children. This research is a descriptive study designed with the survey method. In June 2017, the Certification Program for Teaching Turkish as a Foreign Language was organized for Turkish educators who work in Adana, as a part of “The Project of Supporting Syrian Children's Integration into the Turkish Education System". In this context, all Turkish educators who work in Adana composed the population of this study while 108 Turkish educators constituted the sample of the study. In this study, the data were collected by the "Metacognitive Listening Strategies Opinion Form" developed by the researcher and analyzed with descriptive statistical techniques. The findings of the study showed that most of the metacognitive strategies that can be used before listening are rarely used and that the response rates as to "always" or "often" in the questionnaire are quite low. It was observed that Turkish educators usually "rarely" used strategies apart from the strategy of "underlining words the meaning of which they do not know" in the listening process.

The findings further indicated that more strategies were used before and after listening than during listening and that the most frequently used strategies by learners were summarizing the listening text in their own words, expressing the theme and main idea of the text they were listening to, telling which section/s in the listening text they mostly focused on, and answering the listening comprehension questions.
\end{abstract}

Keywords: Turkish as a foreign language, metacognitive strategies, listening skills

\section{Introduction}

Listening, which plays quite a significant role in the process of establishing communication and language learning, is the most frequently used language skill both in daily life and school life (Chou, 2017). Listening is the most frequently used language skill (Scarcella \& Oxford, 1992). Listening contributes to the development of other language skills in the process of language learning, in addition to being the language skill that develops first. In the process of learning a new language, it develops quicker than the speaking skill and becomes an indispensable skill that affects the development of the reading and writing skills (Oxford, 1993). Despite this importance, listening skill was not regarded as a significant part of language teaching programs until the 1970s (Rost, 2001), and it was a neglected language skill by researchers and teachers (Oxford, 1993). Most teachers believed that listening was developed by children themselves in a natural way, just as walking, therefore, they accepted listening as a natural skill and thought that there was no need to teach listening (Landry, 1969). Nevertheless, listening is more than what a student hears with two ears. Listening is a conscious effort based on perceiving and understanding, evaluating and reacting, which requires an active mental process.

Listening is an act in which many actions are realized together and in a complementing way. In other words, it is a whole of actions with a specific organizational flow. In this sense, listening is a time-based, progressive and transactional process. Listening as a process consists of the stages of hearing by paying attention to the message of a speaker, analyzing and interpreting the code of the message heard, remembering the message interpreted, critical thinking, making a judgement about the message and reacting to the speaker (Brownell, 1985, Quoted by Gürel \& Tat, 2012: 277). In this context, understanding what one listens to requires conscious planning in learning the first or second language, and it is defined as the process of understanding the speech (Richards \& Schmidt, 2007).

Listening in a foreign language is a complex but low-valued skill (Graham, 2003). Researchers must pay attention to the listening skill since it plays a vital role in the development of the speaking skill in the target language to be learned and meaningful mental activities. It is closely related to conscious actions performed by the listener who prefers 
problem-solving as a learning style (Ehrman, Leaver \& Oxford, 2003). Therefore, the act of listening that is performed in the real sense requires a mental process in which the listener is active. Hence, listening training should focus on interactive and participatory listening which requires a more active role of the listener by giving feedback in order to make sure whether communication is successful (Vandergrift, 1997).

Cross (2010) emphasizes that learning how to listen, as well as teaching how to listen, is very difficult. The listening training process can be addressed under three main titles: pre-listening, while listening and post-listening. The succession of these three stages is crucial for the acquisition of the listening skill and turning it into a habit (Quoted by Melanlığlu, 2015: 392). Vandergrift (1999) also emphasized that the stages of listening are important. The researcher pointed out that planning, monitoring, and evaluation are the stages of metacognition, and added that these stages will lead students to cognitive processes in order to effectively understand what one listens to.

\subsection{Metacognition and Listening}

Teachers must realize that listening will be a stressful activity for language learners (Goh \& Taib, 2006). This skill is a very complex process since the memories of second language learners have limited competence in the target language (Richards, 1983). Therefore, strategy use is important in language learning, and using a strategy is required for active and self-directed participation that is necessary to improve communication skills (Oxford, 1990: 10). Certain studies conducted (Rubin, 1994; Lynch, 1998; Vandergrift, 2004; Flowerdew \& Miller, 2005; Macaro, Graham \& Vanderplank, 2007, Quoted by Goh, 2008) point to new approaches that are influenced by linguistic and cognitive psychological developments in teaching listening. One of them is the metacognitive approach. Flavell (1979: 906) defined metacognition as thinking about thinking and stated that metacognition has two components. These are knowledge and organization. Metacognitive knowledge includes information about the individual himself/herself as a learner, about strategies, and when and why to use these strategies (Kuhn \& Dean, 2004). Organization, which is the other component, includes planning, monitoring, and evaluation activities (Vandergrift, 2002, 2003; Chamot, 2005).

Metacognition plays an important role in most cognitive activities such as establishing communication, verbal persuasion, understanding what is being said, reading comprehension, and writing (Flavell, 1976). Metacognition strategies are used to plan, monitor and evaluate the learning process, define long and short-term goals, and to check whether language learners have understood during a listening task (Oxford, 1990). Upon examining the practices performed before, during and after listening, it is understood that all of them consist of the stages that require learners to be involved in the process. This requires students to use metacognitive skills (Melanlığlu, 2015: 393). Language learners who are aware of the benefits of listening strategies can use these strategies to develop their listening comprehension during communication (Zhang \& Goh, 2006).

There are certain findings indicating that teaching of metacognitive strategies has various benefits in listening training. These strategies help language learners to become more self-confident and motivated, and less anxious. It positively affects listening performance and contributes to the listening potentials of poor listeners to be better. However, it is clear that more research on the role of teaching the metacognitive strategies is needed (Goh, 2008: 197). As a result of two studies conducted by Vandergrift (2007) and Zeng (2007), it was found out that there is a statistically clear correlation between metacognitive strategy teaching and the improvement of listening performance (Quoted by Goh, 2008). As a result of the study conducted by Thompson and Rubin (1996) with students learning Russian as a foreign language, it was found out that strategy teaching in listening training improves the listening comprehension skills of students. No study was encountered on the use of metacognitive strategies and the effect of these strategies on listening performance for improving the listening skill in teaching Turkish as a foreign language. In this context, what kind of a path teachers of Turkish as a foreign language follow in the process of developing the listening skill and whether they can ensure the use of metacognitive strategies that will enrich this process are an important subject. The process of introducing the language skills in teaching Turkish to the Syrians coming to Turkey is of great importance, as well. Especially, in order to support the integration of Syrian children into the Turkish education system, it is necessary to raise awareness of how to organize language teaching activities, and it is required to develop the listening skill, which is a significant comprehension skill, using various methods. It was thought that which arrangements are needed to teach metacognitive strategies in the process of developing the listening skill in teaching Turkish as a foreign language will be possible to determine using the data to be obtained by means of research. Thus, it is hoped that Syrian students will learn Turkish effectively and that the listening skill which will help them to adapt to the culture together with the language will also be improved in a more effective manner. Based on this significance, the aim of the present study is to determine the state of using metacognitive strategies for the development of listening skills in the teaching of Turkish as a foreign language to Syrian children. To this end, the answers to the following questions were sought:

\subsection{Regarding the Teachers Teaching Turkish to Syrian Children}

-What are the metacognitive strategies they use pre-listening?

- What are the metacognitive strategies they use during the process of listening? 
- What are the metacognitive strategies they use post-listening?

\section{Method}

\subsection{Research Design}

This research is a descriptive study designed in the screening model. Screening models aim to describe a past or present situation as it is and therefore it is thought that this model is suitable for the aim of the study (Karasar, 2000).

\subsection{Population and Sample}

A Certification Program for Teaching Turkish as a Foreign Language was organized in June 2017 for Turkish educators working in Adana province within the scope of the "Project of Supporting Syrian Children's Integration into the Turkish Education System" implemented by the Ministry of National Education under the protocol signed between Çukurova University Rectorate and Adana Provincial National Education Directorate. In this context, while the population of the study consisted of all Turkish educators working in Adana province, the sample consisted of 122 Turkish educators who were assigned to the first stage of the training given within this project. Nevertheless, the data collected from 108 of 122 Turkish educators were included in the study and the other teachers were excluded since they did not fully fill in the opinion forms distributed to them. The demographic profile of the Turkish educators that participated in the study is presented in Table 1.

Table 1. Demographic Profile of the Turkish Educators that Participated in the Study

\begin{tabular}{llll}
\hline Features & f & \% \\
\hline Female & 68 & 63 \\
Male & 40 & 37 \\
Faculty of Education & 104 & 97.2 \\
Faculty of Science and Letters & 3 & 2.7 \\
Other (Faculty of Language, History-Geography) & 1 & 0.9 \\
Turkish Teaching & 26 & 24.1 \\
Primary School Teaching & 73 & 67.6 \\
Turkish Language and Literature Teaching & 5 & 4.7 \\
Turkish Language and Literature & 3 & 2.8 \\
Linguistics & 1 & 0.9 \\
0-5 Years & 100 & 92.6 \\
6-10 Years & 2 & 1.9 \\
11-15 Years & 3 & 2.8 \\
16-20 Years & 3 & 2.8 \\
2nd Grade & 31 & 28.7 \\
& 3rd Grade & 23 & 21.3 \\
& 4th Grade & 11 & 10.2 \\
& 5th Grade & 8 & 7.4 \\
6th Grade & 6 & 5.6 \\
7th Grade & 9 & 8.3 \\
8th Grade & 9 & 8.3 \\
9th Grade & 4 & 3.7 \\
10th Grade & 2 & 1.9 \\
11th Grade & 1 & 0.9 \\
\hline \multirow{2}{*}{ 12th Grade } & 4 & 3.7 \\
\hline
\end{tabular}

As it is seen from Table 1, 68 of the Turkish educators that participated in the study were female, 40 were male, and the majority were graduates of the faculty of education. 26 of the Turkish educators graduated from the Department of Turkish teaching, 73 graduated from the Department of Primary School Teaching, 5 graduated from the Department of Turkish Language and Literature Teaching, 3 graduated from the Department of Turkish Language and Literature, and 1 graduated from the Department of Linguistics. Most of the participants had 0-5 years of seniority, and they taught Turkish to children at different grade levels, from second to twelfth grade.

\subsection{Data Collection and Analysis}

The data in the study were collected by using the "Metacognitive Listening Strategies Opinion Form" developed by the researcher. The items of the form include strategies that can be used pre-listening, whilw-listening and post-listening. The form consists of 21 items in total, and it was developed in a 5-point Likert type. The relationship between metacognition and language education, and metacognition and listening skills, and the relevant literature on metacognition in the foreign language teaching were used in the process of developing the form, and the items in the form were created in this context. Furthermore, the opinions of the specialists in the field of teaching Turkish as a native language and foreign language were 
taken. The form was applied to 20 Turkish educators as a pilot scheme one week before the start of lessons for listening training. Corrections were made in a number of items that needed to be expressed more clearly from the linguistic aspect based on the feedback received from the specialists and Turkish educators, and the form was put into final form. The data were collected after the lessons in which the researcher also took part as an instructor within the scope of the "Certification Program for Teaching Turkish as a Foreign Language", by distributing the forms to Turkish educators and giving them at least 20 minutes to fill them in. Turkish educators were asked to express their level of agreement with the items in the form, taking into account the 5-point rating scale from "never (1)" to "always (5)". The data were analyzed using descriptive statistics techniques by means of the SPSS package program.

\section{Findings}

The findings obtained from the Metacognitive Listening Strategies Opinion Form used to determine to what extent Turkish educators included metacognitive strategies pre-listening, while-listening and post-listening within the scope of the study are presented in Table 2.

Table 2. Metacognitive Strategies of Educators Turkish in Listening Training

\begin{tabular}{|c|c|c|c|c|c|c|c|c|c|c|c|c|}
\hline \multirow{2}{*}{ ITEMS } & \multirow{2}{*}{$\mathbf{N}$} & \multirow{2}{*}{$\overline{\mathrm{X}}$} & \multicolumn{2}{|c|}{ Never } & \multicolumn{2}{|c|}{ Rarely } & \multicolumn{2}{|c|}{ Sometimes } & \multicolumn{2}{|c|}{ Frequently } & \multicolumn{2}{|c|}{ Always } \\
\hline & & & f & $\%$ & f & $\%$ & f & $\%$ & f & $\%$ & f & $\%$ \\
\hline $\begin{array}{l}\text { 1. I ensure that students remember the preliminary information about the topic they will } \\
\text { listen to in the listening training. }\end{array}$ & 108 & 2.48 & 12 & 11.1 & 48 & 44.4 & 35 & 32.4 & 10 & 9.3 & 3 & 2.8 \\
\hline 2. I guide students to determine their listening aims pre-listening. & 108 & 2.07 & 30 & 27.8 & 49 & 45.4 & 22 & 20.4 & 5 & 4.6 & 2 & 1.9 \\
\hline 3. I ensure that students take notes of their listening aims pre- listening. & 108 & 2.07 & 30 & 27.8 & 49 & 45.4 & 22 & 20.4 & 5 & 4.6 & 2 & 1.9 \\
\hline $\begin{array}{l}\text { 4. I guide students in order for them to plan what they need to do while listening } \\
\text { pre-listening. }\end{array}$ & 108 & 2.24 & 26 & 24.1 & 44 & 40.7 & 25 & 23.1 & 12 & 11.1 & 1 & 0.9 \\
\hline $\begin{array}{l}\text { 5. I ask students to express their predictions about the content by telling the title of the } \\
\text { text to which they will listen. }\end{array}$ & 108 & 2.31 & 28 & 25.9 & 39 & 36.1 & 21 & 19.4 & 19 & 17.6 & 1 & 0.9 \\
\hline $\begin{array}{l}\text { 6. I ask students to make predictions about the content by showing them visuals related } \\
\text { to the text they will listen to. }\end{array}$ & 108 & 2.49 & 25 & 23.1 & 33 & 30.6 & 25 & 23.1 & 22 & 20.4 & 3 & 2.8 \\
\hline 7. I tell students to focus on the text they will listen to before listening. & 108 & 2.89 & 14 & 13 & 29 & 26.9 & 27 & 25 & 31 & 28.7 & 7 & 6.5 \\
\hline 8. I guide students in order for them to identify keywords while listening. & 108 & 2.07 & 25 & 23.1 & 52 & 48.1 & 29 & 26.9 & 2 & 1.9 & - & - \\
\hline 9. I tell students to question whether they understand what they listen to while listening. & 108 & 2.14 & 29 & 26.9 & 45 & 41.7 & 24 & 22.2 & 10 & 9.3 & - & - \\
\hline $\begin{array}{l}\text { 10. I tell students to picture in their mind so that they can understand what they listen to } \\
\text { better. }\end{array}$ & 108 & 2.18 & 31 & 28.7 & 41 & 38 & 26 & 24.1 & 6 & 5.6 & 4 & 3.7 \\
\hline 11. I tell students to underline the important information while listening. & 108 & 2.16 & 28 & 25.9 & 43 & 39.8 & 30 & 27.8 & 6 & 5.6 & 1 & 0.9 \\
\hline 12. I tell students to underline the new words while listening. & 108 & 3.76 & 1 & 0.9 & 7 & 6.5 & 29 & 26.9 & 51 & 47.2 & 20 & 18.5 \\
\hline $\begin{array}{l}\text { 13. I ask students to assess the contribution of the speaker's emphasis and intonation } \\
\text { while listening. }\end{array}$ & 108 & 2.08 & 30 & 27.8 & 48 & 44.4 & 23 & 21.3 & 5 & 4.6 & 2 & 1.9 \\
\hline 14. I tell students to check whether they have achieved their aims post-listening. & 108 & 2.08 & 30 & 27.8 & 48 & 44.4 & 23 & 21.3 & 5 & 4.6 & 2 & 1.9 \\
\hline $\begin{array}{l}\text { 15. I ask students to compare whether the predictions they have made pre-listening } \\
\text { overlap with what they have learned post-listening. }\end{array}$ & 108 & 2.50 & 25 & 23.1 & 32 & 29.6 & 26 & 24.1 & 22 & 20.4 & 3 & 2.8 \\
\hline 16. I ask students to summarize what they have listened to in their own words. & 108 & 4.31 & - & - & 2 & 1.9 & 7 & 6.5 & 55 & 50.9 & 44 & 40.7 \\
\hline $\begin{array}{l}\text { 17. I ask students to tell the subject and main idea (or the conclusion) of the text that } \\
\text { they have listened to. }\end{array}$ & 108 & 4.31 & - & - & 2 & 1.9 & 7 & 6.5 & 55 & 50.9 & 44 & 40.7 \\
\hline $\begin{array}{l}\text { 18. I ask students to tell which part(s) they have focused on most in the text they have } \\
\text { listened to. }\end{array}$ & 108 & 4.12 & - & - & 4 & 3.7 & 12 & 11.1 & 59 & 54.6 & 33 & 30.6 \\
\hline 19. I ask students to answer questions on what they have listened to. & 108 & 4.06 & 1 & 0.9 & 2 & 1.9 & 14 & 13 & 63 & 58.3 & 28 & 25.9 \\
\hline 20. I ask students to assess their own listening process. & 108 & 2.18 & 31 & 28.7 & 41 & 38 & 26 & 24.1 & 6 & 5.6 & 4 & 3.7 \\
\hline 21. I ask students to assess the suitability of the strategies they use post-listening. & 108 & 2.07 & 25 & 23.1 & 52 & 48.1 & 29 & 26.9 & 2 & 1.9 & - & - \\
\hline
\end{tabular}

As seen from Table 2, the first seven items in the "Metacognitive Listening Strategies Opinion Form" are metacognitive strategies that can be used pre-listening. It was thought that strategies that are believed to be used before listening are strategies such as ensuring that students remember preliminary information on the subject they will listen to, determining their listening aims and ensuring that they take notes of them, making students predict the content based on the title of the text or visuals, and focusing on the text to be listened to. When the findings are examined, it is observed that the strategies that can be used pre- listening are mostly used "rarely", and their usage rate of "always" and "frequently" is quite low.

Items no 8, 9, 10, 11, 12 and 13 in the "Metacognitive Listening Strategies Opinion Form" are metacognitive strategies that can be used in the listening process. Whether strategies such as guiding students to identify keywords while listening, ensuring that they question whether they have understood while listening, encouraging them to picture in their mind, underline important information, and underline the new words were included in the listening process was investigated. It was determined that Turkish educators mostly "rarely" use the strategies that can be used in the listening 
process, apart from the strategy of "underlining the new words the meaning of which they do not know". It is observed that most of the Turkish educators (47\%) frequently use the strategy of ensuring that students underline words the meaning of which they do not know in the listening process. Based on these findings, it can be said that the usage rate of metacognitive strategies in the listening process is similar to the usage rate of strategies pre-listening.

Metacognitive strategies that can be used after listening are expressed between the $14^{\text {th }}$ and $21^{\text {st }}$ items in the form. In Table 2 , it is observed that the answers on the usage of the items "I tell students to check whether they have achieved their aims post-listening." and "I ask students to compare whether the predictions they have made pre-listening overlap with what they have learned post-listening." concentrate in the options rarely and never. It was found out that the strategies of determining the aim of listening and making predictions on the content based on the title and visuals are also included in the pre-listening stage, and their post-listening usages refer to pre-listening; in this context, the usage rates of these strategies before and after listening were found to be similar. It was determined that the most frequently used strategies post-listening are strategies expressed in the items 16, 17, 18 and 19 and that most Turkish educators use these strategies frequently. These strategies are summarizing what they listen to with their own words, telling the subject and the main idea of the text they have listened to, telling which part(s) they most focused on in the text they have listened to, and answering questions on what they have listened to. The usage rate of the strategies for the students' assessment of their own listening processes and assessing the appropriateness of the strategies they used after listening were also found to be very low. It is possible to say that this finding is related to the lack of strategy usage in general during the development of listening skill.

\section{Discussion, Conclusion and Suggestions}

In the present study, which aims to determine the use of metacognitive strategies for improving listening skill in teaching Turkish to Syrian children, the metacognitive strategies that Turkish educators use pre-listening, while-listening and post-listening were determined. Upon examining the metacognitive strategies that can be used pre-listening, it was found out that most of them are rarely used, and their "always" and "frequently" usage rates are quite low whereas activities pre-listening form a basis for better understanding what one listens to while preparing students for the listening text mentally and psychologically. According to Underwood (1989), the activities before listening are used to activate the preliminary information and help students prepare themselves for the listening process. Therefore, when listening lessons are planned, it is necessary to allocate time for activities pre-listening. In the process of teaching Turkish as a foreign language, language teachers may get the opportunity to get information about the preliminary knowledge, experiences and the level of using the target language of students regarding the text they will listen to with the help of these activities. According to Buck (1995), teachers should be encouraged to use pre-listening activities in order to increase students' awareness of the listening process (Quoted by Goh, 2008: 191). In this context, it is necessary to include the use of strategies pre-listening in teaching Turkish as a foreign language.

One of the findings obtained as a result of the study is about the metacognitive strategies that can be used in the listening process. It was determined that most Turkish educators "rarely" use the strategies that can be used in the listening process, apart from the strategy of "underlining the new words". In this context, it can be said that the usage rate of metacognitive strategies in the listening process is similar to the usage rate of strategies pre-listening, and it is quite low. Nevertheless, the fact that the listening skill has a positive effect on the overall language skills and the ability of the message to be perceived correctly by the listener necessitate the planning of actions that will activate students while listening. Therefore, this stage, i.e. while listening, is aimed at revealing the messages by students and improving the ability of students to analyze (İnce \& Boztilki, 2016: 166).

Another finding is the extent to which the metacognitive strategies that can be used post-listening are actually used. In this context, it was determined that the usage rate of strategies of checking whether the aim is achieved post-listening, comparing whether the predictions made pre-listening overlap with what is learned post-listening and the assessment of the suitability of students' own listening processes and the strategies used post-listening are quite low. However, it was observed that more strategies were used post- listening when compared to the pre-listening and while listening, and the most frequently used strategies are summarizing what they listen to with their own words, expressing the subject and main idea of the text they listen to, and telling which part(s) they have focused on most in the text they have listened to, and answering the questions about what is listened to. The findings on the usage of strategies post-listening show that the conclusion of the listening is focused on in the process of teaching Turkish to Syrian children, and strategies that will reveal whether students have understood what they have listened to are included more. In the light of the findings obtained as a result of the study, it can be said that sufficient metacognitive strategies are not used in teaching Turkish to Syrian children in order to improve their listening skills especially pre-listening and while listening whereas metacognition focuses on the listening process rather than how listening is concluded. Similarly, as a result of the study carried out by Alhaisoni (2017), it was also determined that evaluation, one of metacognitive listening strategies, in other words, the strategies used after listening were among the most frequently used strategies. Nevertheless, the findings obtained in some studies are different from the research result. For example, in the study carried out by Vandergrift (2003), the relationship 
between the type of strategies used and the strategy use and listening proficiency was investigated, and it was determined as a result of the study that students used planning and monitoring strategies, that are the metacognitive strategies used pre-listening and while-listening processes, but they did not use the evaluation strategies post-listening. In the study carried out by Wang (2002), the listening strategies used by EFL students in Taiwan were investigated, and it was determined that metacognition strategies were frequently used during the listening process. Similarly, in the study carried out by Altuwairesh (2016), it was also determined that the strategies for monitoring and problem identification that reflect the listening process were used more often. Strategy instruction in the skill of listening is still very much in its infancy (Macaro, Graham \& Vanderplank, 2007, 185). The aim of the strategy training is to increase learners' awareness about making decisions concerning their own strategy use to tackle language tasks. Strategy training implies that the learners can take control of their own learning by planning a goal, monitoring the processes, and evaluating the learning outcomes. This implies that nurturing learners' metacognition is the key to successful learning (Alhaisoni, 2017, 119).

In the development of listening comprehension skills, as a result of certain studies investigating the use of metacognitive strategies, it was found out in general that good listeners use more metacognitive strategies and the use of these strategies improves the listening performance of language learners (Vandergrift, 2003; Goh \& Taib, 2006; Vandergrift \& Tafaghodtari, 2010). Metacognitive strategies also contribute to developing skills that include understanding, memorizing, planning, monitoring, assessing, and problem-solving for second language learners (O'Malley, Chamot, \& Kupper, 1989). According to Vandergrift (1999), these strategies play a vital role that facilitates this process since they directly command the language learning process. Therefore, the use of metacognitive strategies by the learners of Turkish as a second language in activities aimed at listening will contribute to learning the target language effectively and raising awareness of the target language. In the light of this information, it can be said that the use of metacognitive strategies in order to improve the listening skills in teaching Turkish as a foreign language to Syrian students is quite important, and the following suggestions can be made based on the findings obtained from the study:

Metacognitive strategies and listening activities should be integrated in teaching Turkish as a foreign language.

Training should be provided on how to use metacognitive strategies in the process of developing language skills for the teachers of Turkish as a foreign language.

Teachers of Turkish as a foreign language should act as a model for the learners of the target language in terms of the strategy use when performing listening activities and should provide them with information on how and when to use these strategies.

The listening materials that can be used in teaching Turkish as a foreign language should be arranged in such a way that they include metacognitive strategies or new materials should be developed.

\section{References}

Alhaisoni, E. (2017). Metacognitive listening strategies used by saudi efl medical students. English Language Teaching, 10(2), 114-122. https://doi.org/10.5539/elt.v10n2p114

Altuwairesh, N. (2016). EFL Saudi Undergraduate Students' Use of Metacognitive Listening Strategies. Arab World English Journal, 7(1), 78-93. https://doi.org/10.24093/awej/vol7no1.6

Chamot, A. (2005). Language learning strategy instruction: Current issues and research. Annual Review of Applied Linguistics, 25, 112-130. https://doi.org/10.1017/S0267190505000061

Chou, M. H. (2017). A task-based language teaching approach to developing metacognitive strategies for listening comprehension. Journal of Listening, 31, 51-70. https://doi.org/10.1080/10904018.2015.1098542

Ehrman, M., Leaver, B. L., \& Oxford, R. L. (2003). A brief overview of individual differences in second language learning. System, 31, 313-330. https://doi.org/10.1016/S0346-251X(03)00045-9

Flavell, J. H. (1976). Metacognitive aspects of problem solving. In L. B. Resnick (Ed.), The nature of intelligence (pp. 231-235). NJ: Hillsdale.

Flavell, J. H. (1979). Metacognition and cognitive monitoring: A new area of cognitive developmental inquiry. American Psychologist, 34, 906- 911. https://doi.org/10.1037/0003-066X.34.10.906

Goh, C. (2008). Metacognitive instruction for second language listening development: theory, practice and research implications. RELC Journal, 39 (2), 188-213. https://doi.org/10.1177/0033688208092184

Goh, C., \& Taib, Y. (2006). Metacognitive instruction in listening for young learners. ELT Journal, 60, 222-232. https://doi.org/10.1093/elt/ccl002

Graham, S. (2003). Learner strategies and advanced level listening comprehension. Language Learning Journal, 28, 64-69. https://doi.org/10.1080/09571730385200221 
Gürel, E., \& Tat, M. (2012). Bir iletişim edimi olarak dinleme ve Türkçe'de bulunan dinleme temalı atasözleri ile deyimler üzerine bir içerik analizi. Uluslararası Sosyal Araştırmalar Dergisi, 5(23), 276-297.

İnce, B., \& Boztilki, G. (2016). Yabancı dil olarak Türkçe öğretiminde dinleme becerisi. F.,Yıldırım ve B., Tüfekçioğlu (Ed.), Yabancı dil olarak Türkçe ögretimi, kuramlar, yöntemler, beceriler, uygulamalar içinde (s. 157-175). Ankara: Pegema.

Karasar, N. (2000). Bilimsel araştırma yöntemi. (10. Baskl). Ankara: Nobel Yayın Dağıtım.

Kuhn, D., \& Dean, D. (2004). A bridge between cognitive psychology and educational practice. Theory into Practice, 43(4), 268-273. https://doi.org/10.1207/s15430421tip4304_4

Landry D. L. (1969). The neglect of listening. Elementary English, 46(5), 599-605.

Macaro, E., Graham, S., \& Vanderplank, R. (2007). A review of listening strategies: Focus on sources of knowledge and on success. In A. Cohen \& E. Macaro (Eds.), Language learner strategies (pp. 165-185). Oxford: Oxford University Press.

Melanlığlu, D. (2015). Yabancı öğrenciler için dinleme becerisine yönelik üstbilişsel dereceli puanlama anahtarı. Erzincan Üniveristesi Sosyal Bilimler Enstitüsü Dergisi, ÖS-II: 391-404.

O’Malley, J., Chamot, M., \& Kupper, L. (1989). Listening comprehension strategies in second language acquisition. Applied Linguistics, 10(4), 418-437. https://doi.org/10.1093/applin/10.4.418

Oxford, R. (1990). Language learning strategies: What every teacher should know. New York: Newbury House.

Oxford, R. L. (1993). Research update on teaching L2 listening. System, 21(2), 205-211. https://doi.org/10.1016/0346-251X(93)90042-F

Richards, J. C. (1983). Listening comprehension: Approach, design, procedure. TESOL Quarterly, 17(2), 219-240. https://doi.org/10.2307/3586651

Richards, J. C., \& Schmidt, R. (Eds.). (2007). Longman dictionary of language teaching and applied linguistics (3rd ed.). London: Longman.

Rost, M. (2001). Listening. In R. Carter \& D. Nunan (Eds.), The Cambridge guide to teaching English to speakers of other languages (pp. 7-13). Cambridge: Cambridge University Press. https://doi.org/10.1017/CBO9780511667206.002

Scarcella, R. C., \& Oxford, R. L. (1992). The tapestry of language learning: the individual in the communicative classroom. Boston, MA: Heinle \& Heinle

Thompson, I., \& Rubin, J. (1996). Can strategy instruction improve listening comprehension? Foreign Language Annals, 29(3), 331-342. https://doi.org/10.1111/j.1944-9720.1996.tb01246.x

Underwood, M. (1989). Teaching listening. New York: Longman Inc.

Vandergrift, L (1999). Facilitating second language listening comprehension: Acquiring successful strategies. ELT Journal, 53(3), 168-176. https://doi.org/10.1093/elt/53.3.168

Vandergrift, L. (1997). The Cinderella of communication strategies: Reception strategies in interactive listening. The Modern Language Journal, 81(4), 494-505. https://doi.org/10.1111/j.1540-4781.1997.tb05517.x

Vandergrift, L. (2002). It was nice to see that our predictions were right: Developing metacognition in L2 listening comprehension. The Canadian Modern Language Review, 58, 555-575. https://doi.org/10.3138/cmlr.58.4.555

Vandergrift, L. (2003). Orchestrating strategy use: Toward a model of the skilled second language listener student. Language Learning, 53, 463-496. https://doi.org/10.1111/1467-9922.00232

Vandergrift, L., \& Tafaghodtari, M. (2010). Teaching L2 learners how to listen does make a difference: An empirical study. Language Learning, 60(2), 470-497. https://doi.org/10.1111/j.1467-9922.2009.00559.x

Zhang, D., \& Goh, C. (2006). Strategy knowledge and perceived strategy use: singaporean students' awareness of listening and speaking strategies'. Language Awareness, 15, 199-219. https://doi.org/10.2167/la342.0

\section{Copyrights}

Copyright for this article is retained by the author(s), with first publication rights granted to the journal.

This is an open-access article distributed under the terms and conditions of the Creative Commons Attribution license which permits unrestricted use, distribution, and reproduction in any medium, provided the original work is properly cited. 